\title{
Ethical Code of Islamic Psychotherapy in Indonesia
}

\author{
Ahmad Saifuddin ${ }^{1}$ \\ IAIN Surakarta \\ Submitted 15 July 2019 Accepted 31 December 2019 Published 22 June 2020
}

\begin{abstract}
Islamic psychotherapy has been an interesting discussion over the past few years. This is indicated by the number of studies on Islamic psychotherapy, both literature studies and experiments. As a method of psychotherapy, Islamic psychotherapy cannot be separated from ethics code. However, Islamic psychotherapy is based on two principles, namely the science of psychology and Islamic religion. It leads to debate about the form of ethical code of Islamic psychotherapy. This study aimed to provide suggestions for the formulation of a code of ethics in Islamic psychotherapy using literature study. The result is a clear formulation of ethical code of Islamic psychotherapy. The formulation is based on psychology ethics which is then interpreted according to the context of Islamic psychotherapy. It is intended that the perception and implementation of Islamic psychotherapy can be standardized and not leading to ethical violations.
\end{abstract}

Keywords: ethics code; Islamic psychotherapy; psychology

\section{Introduction}

Psychotherapy a pivotal part of psychology. Psychology is comprehended as a scientific field that studies and examines psychiatric condition, mental processes, and human personality through behavior. The foundation of psychology as scientific field was marked by the establishment of psychology laboratory by Wilhelm Wundt in Leipzig, Germany at the end of 19th century (Brock, 2014; Freedheim \& Weiner, 2003). There are three main areas studied in psychology i.e., consciousness, unconsciousness, and human adjustment (Henriques, 2004; Wood, Wood, \& Boyd, 2014). Meanwhile, psychotherapy is defined as treatment modal when therapist and patient work together to improve psychopathological condition and functional disruptions by focusing on therapeutic

\footnotetext{
${ }^{1}$ Address for correspondence:

ahmad_saifuddin48@yahoo.com
}

relation; e.g., attitude, thoughts, influences, and behavior of the patient; as well as context and social development (Brent \& Kolko, 1998).

Since human problems become more complex in this modern era, psychotherapy develops to be more specific and plays a huge role in humans mental health (Marks, 2017). The development of psychotherapy is in line with the development of psychology school of thoughts. It means that psychotherapy model refers to the development of psychology paradigms and thus there are various psychotherapy models, i.e., psychodynamic, behavioral, cognitive, humanistic, transpersonal, and Islamic psychotherapy models. The practice of psychotherapy is guided by psychology code of ethics. The ethics code is general whereas certain psychotherapy models are specific, one of them is Islamic psychotherapy. To this day, there is no definite guideline which regulates the 
implementation of Islamic psychotherapy even though it is crucial as modality framework in achieving optimum psychotherapy results.

Code of ethics in psychotherapy is necessary because every aspect related to psychotherapy is guided by the code. This ethics code has varied purposes i.e., providing clear boundaries about psychotherapy which include party entitled to administer it as well as conditions where psychotherapy is required; responsibilities and set of competence that therapist must fulfill; the etiquette of protecting client's personal information also utilizing information and results of psychological assessment; and fee of psychotherapy services. If those aspects are regulated by ethics code, therapist will be committed to administer the procedures optimally and safeguard client's rights. To conclude, ethics code protects both parties involved from potential loss. In Indonesia, ethics code for psychology and psychotherapy is compiled in Code of Ethics for Psychology in Indonesia (Kode Etik Psikologi Indonesia) formulated by Central Administrator of Indonesian Psychological Association (Pengurus Pusat Himpunan Psikologi Indonesia/PP HIMPSI).

Numerous psychotherapy techniques deliver positive impact on individual's behavioral changes and mental health. Most findings revealed that those psychotherapy models are able to help individual cease abnormal behaviors and improve mental well-being. However, psychotherapy still possesses side effects. A study by Linden and Schermuly-Haupt (2014) revealed some side effects of modern psychotherapy e.g., failure in undergoing therapy procedures, development of new symptoms, suicide, problems at workplace and stigmatization, changes in social network or tensions in relation- ships, dependency on psychotherapy, and damaged self-efficacy. Thus, psychotherapists are expected to have high proficiency and necessary legality as well as able to anticipate possibilities of side effects. Psychotherapists are also required to uphold code of ethics in every session of psychotherapy.

Badri (1979) stated that modern psychotherapy (psychoanalysis, behaviorism, humanistic, transpersonal, et cetera) still possesses several issues. Modern psychotherapy does not regard human's spiritual side and thus cannot solve mental problems thoroughly (Mayasari, 2013; Puji \& Hendriwinaya, 2015; Rajab, 2006). Badri then proposed a concept called Islamic psychotherapy. Islamic psychotherapy is a method to remedy mental and behavioral problems using the principles of Quran and Hadith. Consequently, Islamic psychotherapy tends to adopt worshipping forms as therapy methods, e.g., salat, dhikr, and Quran recitation. In addition, this model of psychotherapy also offers something that is not provided by other modern psychotherapy models, which is improvement in spiritual aspect of life (Haque, Khan, Keshavarzi, \& Rothman, 2016; Haslina et al., 2016; Trimulyaningsih, Wulandari, \& Sofia, 2017). This psychotherapy approach also incorporates tasawuf or Sufism. Tasawuf or sufism is defined as concept or teaching with objective to deepen the insight and practice of Islam, not only through physical rituals but also spiritual cultivation (Bakri \& Saifuddin, 2019).

As time goes by, there are more varied psychotherapy methods which are based on Islamic values. Soliman and Mohamed (2013) found that psychotherapy with dhikr can reduce anxiety problem and another study by Amir, Mastutik, Hasinuddin, and Putra (2018) showed how 
dhikr also reduces cortisol level and stress. Salat was also found to reduce anxiety symptoms, lower blood sugar level, and improve work ethics (Kartika, Rosa, Permana, \& Primanda, 2016; Qodar, Wijaya, \& Amilda, 2017; Sari, Pitoewas, \& Yanzi, 2018; Wardani, Nashori, \& Uyun, 2016; Doufesh, Ibrahim, Ismail, \& Ahmad, 2014). The effectiveness of reciting Quran in reducing stress, depression, and anxiety was studied too (Amanah \& Purnamasari, 2015; Az Zahra \& Saidiyah, 2013; Nugraheni, Mabruri, \& Stanislaus, 2018; Rahmayani, Rohmatin, \& Qulandara, 2018).

Islamic psychotherapy has not established specific ethics code which regulates its practice. At this point, several questions are proposed: what is the strategy to formulate ethical code of Islamic psychotherapy? Is the ethical code by Indonesian Psychological Association sufficient considering that it does not explicitly state the use of religious principles? Should there be another ethics code with an addition of Islamic aspects? Based on the problems, study on the ethics of Islamic psychotherapy becomes very urgent to do. At the end, such study should result in recommendations on how to formulate ethical code of Islamic psychotherapy. The methods suggested are expected to become modalities in forming code of ethics in Islamic psychotherapy as follow-up of the study.

The present study utilized systematic review with library research method. Library research method encompasses retrieving relevant literatures, reading, keeping record, and processing the data. It utilizes various references and literature sources in order to obtain data (Zed, 2016). Systematic review is a research method that includes the activities of assessing, summarizing, and reconciling various previous studies critically (Roberts \& Petticrew, 2006). Systematic review also involves a systematic search process to find all published studies that are both relevant and irrelevant to the research theme being carried out, which addresses one or more research questions, and attempts to synthesize the findings of various previous studies (Siddaway, Wood, \& Hedges, 2019). Literatures used in the study include literatures in the form of books and journals about psychology, Islamic psychology, psychotherapy, Islamic psychotherapy, and ethics code in psychology.

\section{Discussion}

The Need for Ethical Code of Islamic Psychotherapy

According to the systematic review, discussion about ethics in conducting Islamic psychotherapy is found to be necessary. The ethics are required to answer several questions related to the implementation of this psychotherapy model. For examples, what are the criteria and competencies required to provide the psychotherapy service?; how to protect client's personal information in Islamic psychotherapy?; could a psychologist consider this psychotherapy model as the only solution for any psychiatric issue?. If those questions remain unanswered, there would be susceptibility to non-optimal Islamic psychotherapy process.

Discussion about the ethics of Islamic psychotherapy implementation is also important because currently there is no specific code established to regulate it. In conducting psychotherapy, Indonesian psychologists refer to ethical code by Indonesian Psychological Association. Since Islamic psychotherapy is an application of a discourse in psychology 
(Islamic psychology), the current code of ethics is used. However, considering that the code does not explicitly describe the application of Islamic values, potential for debates might arise.

According to Al-Rabae (2009), ethics code in Islamic psychotherapy has different philosophy from modern psychotherapy, which is the inclusion of Islamic perspective. Thus, Islamic psychotherapy still requires its own ethical code which incorporates Islamic principles. This point of view proposes problem, which is the appropriate strategy to formulate a specific ethical code for Islamic psychotherapy. The initial step is to find potential issues in implementing Islamic psychotherapy.

\section{Various Issues in Islamic Psychotherapy}

There are some problems that need to be addressed in the practice of Islamic psychotherapy. As described in the previous part, there are two principles used in this model: psychotherapy and Islamic values. In its course, Islamic psychotherapy integrates worships and prayers in Islam. Within the context of psychotherapy, there is an ethical standard in which therapist is someone who has competence in performing psychotherapy and legality, which means that the person must have completed certain education level namely Master in Professional Psychology (HIMPSI, 2010).

In Islamic psychotherapy, a problem arises from the application of its two main principles when it comes to defining the required competence. The psychotherapist is ideally someone who has the capacity in Islam, fulfilling several indicators i.e., completed education as professional psychologist, received certified training in Islamic psychotherapy, and possesses legality in spirituality. The most notable example of legality in spirituality can be seen in tasawuf or Sufism that is represented by tariqa (Islamic faith community). There is a baiat system in Sufism or tariqa which is defined as an oath to faithfully observe Islam teachings, guided by a murshid (mentor). Thus, the two main principles of Islamic psychotherapy provide clear foundation to describe a competent therapist. Psychotherapist should have proficiency to provide psychotherapy and perform baiat to a Sufism group namely a tariqa. This actually incites another potential issue. Not all Islamic psychotherapists are able and willing to perform baiat to tariqa.

Baiat in Sufism tradition is done when an individual starts to extensively learn Sufism practice in a tariqa community. In the process of baiat, the individual will be guided to develop pure intention and be thoroughly sincere. The practice of baiat in each tariqa community is different. A tariqa may require student to close their eyes, perform qurban or sacrificing a livestock animal, recite dhikr repeatedly, or wear certain robe (Rozehnal, 2007; Setiawan, 2015; Riyadi, 2014; Salahudin, 2016; Ummah, 2018; Howell, 2014).

Although the baiat practices might be different, the purposes remain similar. It aims to align one's orientation in learning the practice of Islam within a certain tariqa, develop strong commitment, and cultivate good relationship with murshid. Good relationship between student and murshid must be established because murshid is going to provide intensive guidance and companionship. Guidance is important because in religion, there should not be any mistake in the practice. In addition, baiat also becomes of moral support from murshid to the student, in forms of prayer and plea for God's blessing. 
Baiat can be likened (although not entirely similar) to application for a degree in psychology, particularly in Master of Professional Psychology. When someone applies to an institution to study the practice of psychology, that person will be mentored by lecturers and experts for a certain period of time. In addition, there is a basic competency level that must be fulfilled and thus requires student to practice intensively before receiving certification as therapist and legally providing psychotherapy. Just like in tariqa community, baiat is required as initiation to start learning under a murshid. With that intensive Islam learning, student will have the competence and experience in practicing Islamic values as well as regulating emotions and feelings. That would provide strong basis for someone to perform Islamic psychotherapy.

Considering baiat to certain tariqa is a high-level of criterion, a therapist can go through an intensive training in Islamic psychotherapy. It is important to note that the therapist should already have proficient understanding in Islamic values and teachings. However, in this case it is likely that therapist's spiritual side is not "fully actualized", unlike the ones who perform baiat to tariqa with the guidance of murshid. It is conflicting because the improvement of client's spirituality is an advantage that Islamic psychotherapy offers.

Another potential issue is related to the practice of psychotherapy. As described in the previous section, this model adopts several worshipping methods as well as prayer and dhikr in its practice. A party who does not possess psychology competency and legality cannot perform psychotherapy. If that principle is applied, a person who does not receive education in professional psychology but has capability of providing mental issue remedies using Islamic approaches (e.g., murshid, tariqa community member, someone who practice ruqyah) might be considered violating the regulation or behaving unprofessionally. If that does not happen, it means that the therapist does not have formal legality in performing the procedure even if they have the necessary competence. On the other hand, Islambased methods of mental issue remedy have been around longer than Islamic psychology and Islamic psychotherapy.

In relation to this matter, deeper interpretation on Code of Ethics for Psychology in Indonesia chapter XIV article 72 about qualifications of counselor and psychotherapist as well as Regulation of the Minister of Health Republic of Indonesia Number 15 Year 2018 about the Enforcement of Complementary Traditional Health article 6 and 8. In addition, an effort to synchronize those two regulations is necessary to be the jumpingoff point in formulating ethical code of Islamic psychotherapy.

Haryati (2018) had explained that the ideal characteristic of individual who performs Islamic psychotherapy or counseling is practicing Islamic values. Practicing the values can be expressed by following a tariqa so that the implementation of Islamic values will be consistent and monitored by a mentor, although it does not necessary have to be the case. Increasing the competence and knowledge about Islamic psychotherapy and counseling can be done by reading periodicals, listening to radio, and watching religious shows (Haryati, 2018). The latter must be further scrutinized because learning about religion is ideally done with a teacher's guidance.

Another issue that can potentially incite a debate is confidentiality. In mo- 
dern psychotherapy, therapist should be able to protect client's confidential information. It is important in maintaining client's self-esteem and averting any form of harm. Even if a therapist needs to discuss a case for learning purpose, they should not disclose client's identity. In fact, the records of psychological assessment and psychotherapy must be kept in a place that is not easily accessible to anyone else.

As discussed previously, Islamic psychotherapy adopts various worshipping rituals and healing methods in Islam. One of them is ruqyah. (Akhmad, 2005; Qodariah, 2015; Setyawan \& Purwanto, 2006; Susanto, 2014; Fadilah, 2015). Ruqyah is a therapy technique that uses verses from the Quran and other instruments as taught by the Prophet Muhammad, i.e., water and sidr leaf. Oftentimes someone without formal psychology training performs ruqyah but does not hide client's face and identity (apart from whether client provides consent or not). If this method (as well as other Islam-based methods) is applied in Islamic psychotherapy, another potential debate whether it is necessary guise client's identity during the therapy process both for licensed psychotherapist or those who are not professional psychologists will arise. If this matter is not decided, there will be two implementation models in conducting Islamic psychotherapy: one is masking client's identity and the other one is not. This will create confusion and ambiguity in its ethical implementation.

Various Ways to Formulate Code of Ethics in Islamic Psychotherapy

Islamic psychotherapy is a study of mental illness healing technique that originated from Islamic values. Therefore, Islamic psychotherapy has become a part of
Islamic psychology discourse. Speaking of Islamic psychology and Islamic psychotherapy, there are two major models of concept. First, the concept explaining that Islamic psychotherapy and Islamic psychology (including its ethical code) are sourced from the Quran and Hadith. The first model tends to deny references from outside of Islam. Meanwhile the second concept, known as Islam-based psychology, explains that Islamic psychotherapy and Islamic psychology (including its ethical code) are not always sourced from Islam but can also be sourced from modern psychology theories as long as they are relevant to Islam values and teachings.

According to Mujib (2017), there are four understandings of Islamic psychology. First, Islamic psychology is likened to the psychology of religion. This kind of understanding is held by parties who are not directly involved in Islamic psychology activities. Second, Islamic psychology is seen as a field of study or course. Thus, it is deemed necessary to be taught in educational institutions that have not been able to integrate all psychology courses with Islamic insights. However, it is no longer needed if the integration has been achieved. Third, Islamic psychology is considered as a perspective and approach. Eventually, Islamic psychology becomes a discourse that has specific branches, e.g., Islamic developmental psychology, Islamic personality psychology, Islamic educational psychology, and Islamic psychotherapy. Fourth, Islamic psychology as an institution. Islamic psychology as an institution aims to develop Islamic psychology concepts and theories then conducting research and publications related to the topic to strengthen the institution. 
Mujib considered that the third and fourth forms are the purposes of Islamic psychology. In relation to Islamic psychotherapy, referring to the third and fourth forms, ethics code in Islamic psychotherapy should be formulated separately from ethical code by Indonesian Psychological Association. However, new potential problem might arise such as dualism in the practice of psychotherapy and the enforcement of ethics code in psychology. Especially considering that psychology profession (which includes psychotherapist) must have an institution to regulate psychology practices (including psychotherapy).

On the other hand, looking at Nashori's opinion (2010), Islamic psychology should not limit itself by taking sources only from Islam but to also use other references outside of Islam as long as they are not conflicting with Islamic values. Therefore, Islamic psychotherapy and its enforcement of ethical code can be derived from ethical code by Indonesian Psychological Association. Meaning, ethical code of Islamic psychotherapy can be made by interpreting ethical code by Indonesian Psychological Association in the context of Islamic values and Islamic psychotherapy.

Nashori's opinion was related to integration and interconnection paradigms. Basically, the paradigms showed that there are links between various scientific fields. This assumption was based on the fact that all scientific disciplines focus on one single object: reality of the universe, although the dimension and focus of each science is different (Faiz, 2007). On the other hand, Kuntowijoyo (2006) argued that the core of integration paradigm is "the effort to unite (not merely combine) God's revelation and the discovery of human mind (integral sciences), not alienating God (secularism), or isolating human (other worldly ascentiantism)". Setiawan (2007) also found that integrative and interconnected approaches are meant as attempts to create connection and linkage between religious and general sciences which are incorporated in natural sciences, social sciences, and humanities (Setiawan, 2007).

Alternative illustration of ethical code for Islamic psychotherapy can be obtained based on previous explanation. First, referring to limitations and opinions about Islamic psychology by Abdul Mujib, the understanding of Islamic psychology and its branches (including Islamic psychotherapy and its ethics code), it is necessary to formulate a new Islamic psychotherapy ethics code which is based solely on the Quran, Hadith, and other religious texts. Badri (1979) stated that modern psychotherapy practice is secular and denies the role of God. It also does not attempt to understand humans based on their nature as God's creatures. Therefore, Muslim psychologist should not follow the modern psychotherapy, including its ethical code. This first formula was also stated by Al-Rabae (2009) who deemed it necessary to create a distinctive ethical code based on Islamic values to carry out Islamic psychotherapy because the philosophical basis of Islamic psychotherapy is different from modern psychotherapy which is considered secular.

Looking further at the alternative, potential dualism of Islamic psychotherapy practice and psychology code of ethics might arise. Whereas in Indonesia, ethical code for psychology was formulated by Indonesian Psychological Association as the only organization authorized to regulate psychology practice in Indonesia. Indonesian Psychological Association might potentially lose its role 
as the sole authority that regulates psychology practice in Indonesia if Islamic psychotherapy practice and its code of conduct are based on the first alternative. In addition, this dualism leads to different psychotherapy and ethical code implementations.

The second alternative refers to limitation of Islamic psychology conveyed by Fuad Nashori. Referring to this limitation, ethics code in Islamic psychotherapy does not have to be specifically formulated. It can refer to ethical code by Indonesian Psychological Association by adjusting its interpretation to the context of Islamic psychotherapy and Islamic values. This is caused by Islamic psychotherapy practice not only drawing sources from religious texts, but also the integration of concept in modern psychotherapy that contains Islamic values. However, this second alternative could cause other potential issues as explained in the previous section. For example, the competence of psychotherapist needs to be clarified, especially the standard competence to conduct Islamic psychotherapy.

Richards and Bergin (2005) wrote a number of concerns related to ethics code that must be considered by psychotherapists who integrate psychotherapy with religion and spirituality. One of them is imposing psychotherapist's religion and spiritual values to clients e.g., assessing client behavior as a mistake and sin. At this point, there may be a contradiction between psychotherapy and Islam. One of the principles in psychotherapy is unconditional acceptance. Psychotherapist should not make judgments about client behavior and accept clients as they are, then encourage them to change their behavior. Meanwhile, in Islam there are restrictions of what one should do and should not do, which lead to the labeling of sinful behavior.

Tracing back to various forms of abnormal behavior that need to be taken care of with psychotherapy, it will be apparent that most of the abnormal behaviors will be considered as sins in Islamic paradigm. For example, LesbianGay-Bisexual-Transsexual (LGBT) behavior, paraphilia behavior (e.g., exhibitionism, voyeurism, fetishism, sadism, masochism, et cetera), suicidal ideation, kleptomania (although it cannot be equated with stealing behavior), and substances-related disorders e.g., addiction to substances such as cannabis, cocaine, and other hallucinogens.

If an Islamic psychotherapist works with such client and prioritizes the judgment of sin against the client, it could result to client's demotivation in changing behavior. Moreover, it might incite guilt which could later lead to other psychological problems. However, if the psychotherapist does not consider the act as sin, it is the same as violating the religious values they personally uphold.

Related to those ethics, a middle ground can be drawn up. Islamic psychotherapist should prioritize unconditional acceptance toward client and client can trust Islamic psychotherapist to conduct psychotherapy. When client has trusted Islamic psychotherapist, they can integrate religious values to psychotherapy without judging client as "a sinner who will later be punished in the afterlife". The important thing to underline is that unconditional positive regard does not equal to Islamic psychotherapist assuming the client's abnormal behavior as decent. However, unconditional positive regard is treated as strategy to build rapport with client so that client can trust the therapist and then they will be able to conduct the 
therapy. Basically, psychotherapy (including Islamic psychotherapy) aims to adjust abnormal behavior into more acceptable one. Even further, Islamic psychotherapy can hopefully lead individuals to get closer to God.

Furthermore, Richards and Bergin (2005) also stressed that psychotherapist should not perform practice that is outside their competence. This means that psychotherapist should not feel compelled to use certain techniques outside of their expertise, including Islamic psychotherapy. Based on that, in this context, the use of Islamic psychotherapy is not absolute and mandatory for every Islamic psychotherapist. If a Muslim psychotherapist forces oneself to perform this psychotherapy model, consequently the results will be less optimal and more likely to harm the client. At this point a potential violation of ethical code could appear. Therefore, the use of Islamic psychotherapy can be done if it meets the requirements, for example the psychotherapist does have competence in that regard and technique used in the therapy is relevant to problems faced by client.

It does not mean that psychotherapist only masters few psychotherapy techniques. Every psychotherapist has studied plenty psychotherapy techniques from various paradigms. However, due to limitation in energy, mind power, and abilities, psychotherapists can only focus on few psychotherapy techniques without limiting the opportunity to learn techniques from another paradigm. Thus, psychotherapists can conduct psychotherapy from various paradigms, but their expertise only lies in certain psychotherapy techniques. Similar situation also applies in Islamic psychotherapy context. If psychotherapist is unable to study Islamic psychotherapy, there is no need to enforce it. On the other side, if client problem is not suitable to be solved with Islamic psychotherapy, then the psychotherapist can use another psychotherapy technique from different paradigm.

Islamic psychotherapy is indeed abstracted from the Quran and Hadith which are considered primary sources in Islam. Both came from God and the Prophet Muhammad who became the absolute guides in Islam. However, Islamic psychotherapy as the application of these sources has relativity because it has been mixed with other factors. Thus, the inability of Islamic psychotherapy to be used in some cases does not necessarily become weakness. In contrast, Muslim psychotherapist should not assume that Islamic psychotherapy is the most comprehensive solution to all mental disorders. Such assumption would potentially cause coercion in the use of psychotherapy technique to client and is also vulnerable to violation of ethical code.

Pargament (2011) argued that religiosity or spirituality of the psychotherapist does not automatically help them conducting psychotherapy based on spirituality. Even more important is therapist willingness for openness, sensitivity, and volition to find role in client's spiritual life.

Recommendation to Formulate Ethical Code of Islamic Psychotherapy by Interpreting Code of Ethics for Psychology in Indonesia

Ethical code in Islamic psychotherapy needs special attention to ensure optimum implementation of Islamic psychotherapy. Based on the discussion, there are various alternatives that can be proposed to establish code of ethics in Islamic psychotherapy. The most possible alternative is ethical code of Islamic psychotherapy that roots in ethical code by Indonesian Psychological Association. Nevertheless, 
Islamic psychotherapists can compile and design interpretation of ethical code by Indonesian Psychological Association to address ethical issues in Islamic psychotherapy. The interpretation can be adapted to Islamic psychotherapy modalities and needs. Simply put, Islamic psychotherapist can compile "book of exegesis" according to ethical code by Indonesian Psychological Association.

For example, ethical code by Indonesian Psychological Association article 9 stated that psychologists and/or psychology scientists must make decision based on scientific knowledge and professional attitudes that have been tested and widely accepted or universal in psychology discipline. Based on the interpretation of said article, it needs to be made clear that Islamic psychotherapy has empirical basis from scientific researches thus it is not solely based on mere belief or fanaticism of Islamic psychotherapy paradigm.

The second example, ethical code by Indonesian Psychological Association article 8 stated that psychologists and/or psychology scientists must carry out continuous efforts to maintain and improve their competence. The interpretation on this matter, that to increase competence in Islamic psychotherapy context, therapist can plead allegiance to the tariqa, attend Islamic psychotherapy training, increase readings related to Islamic psychotherapy, and the like.

The third example, Code of Ethics for Psychology in Indonesia article 17 stated that psychologists and/or psychology scientists must avoid taking professional roles if personal, scientific, professional, legal, financial, and other interests or relationships could damage their objectivity, competence, or effectiveness in carrying out role as psychologist and/or psychology researcher or has negative impacts on users of psychological services as well as parties related to the users of these psychological services. Related to the article, it is necessary to formulate an interpretation that the use of Islamic psychotherapy is based on empirical grounds and its appropriateness to the problems faced by clients, not based on discourse sentiments in psychology.

The fourth example, Code of Ethics for Psychology in Indonesia article 72 stated that counselor/psychotherapist is someone who: a) has the competence and qualification to conduct psychology counseling/ therapy independently and/or under supervision to conduct it in accordance with psychology counseling/therapy regulations, b) prioritizes professional principles, c) provides counseling or therapy services to those who need it, $d$ ) is responsible to avoid adverse effects due to counseling or therapy process that is conducted on client. The interpretation of said article needs to stress that Islamic psychotherapists are those who have completed degree in Master of Professional Psychology (in Indonesian context) and adhered to legitimate congregation tariqa (mu'tabar) also guided by murshid, and at least understood the knowledge of Islam and attended Islamic psychotherapy training as well as fulfilling other criteria needed in Islamic psychotherapy.

The fifth example, Code of Ethics for Psychology in Indonesia article 2 section 2 stated that psychologists and/or psychology scientists must respect everyone along with their individual rights to privacy, confidentiality, and personal choices. The interpretation of said article in Islamic psychotherapy context is that psychotherapist should not make judgment and label client who have abnormalities in order to respect their rights so they can get sense of security and 
comfort. This includes avoiding to say that client behavior is sinful. Unconditional positive regard does not mean justifying abnormalities, but as a way to gain client's confidence. When client shows trust, sense of security, and sense of comfort, Islamic psychotherapist can guide and empower client to overcome their problems. In addition, confidentiality can be guaranteed by storing information and psychotherapy files in special place with limited access and putting expiry period so that the files must be destroyed if they exceed the expiry limit. Publication of information and psychotherapy can be done by disguising client's name and face (if needed). This attitude should also be carried by whoever conducting Islamic psychotherapy as manifestation of secrecy ethic in Islam.

The development of interpretation of Code of Ethics for Psychology in Indonesia should be prepared together with Indonesian Psychological Association. The alternative was chosen to avoid dualism in ethics code and psychotherapy practice in Indonesia. It could also accommodate the possibility of ethical code development, including its implementation in Islamic psychotherapy.

\section{Conclusion}

As Islamic psychotherapy is developing, formulating ethical code to regulate its implementation is necessary. If ethical code in Islamic psychotherapy is formulated separately from Code of Ethics for Psychology in Indonesia, dualism might arise. Therefore, the formulation of ethical code for Islamic psychotherapy could be done by interpreting ethical code by Indonesian Psychological Association then adjusting it to Islamic psychology and psychotherapy context. This interpretation should be done by involving Indonesian Psychological Association and Islamic psychologists.

This study aimed to increase awareness of the importance of ethics code in Islamic psychotherapy and generate recommendations on how to formulate it. Therefore, more in-depth and comprehensive studies are needed to be able to formulate ethical code of Islamic psychotherapy by related parties.

This study also seeks to make an impact in the drafting of a code of ethics of Islamic psychotherapy within Indonesian context. It becomes especially important as Indonesia sees we can see rapid development of Islamic psychotherapy because the majority of Indonesian people are Muslims. According to Nashori, Diana, and Hidayat (2019), the trend of Islamic psychotherapy in Indonesia has increased and come in varied forms. On the other hand, nearly all forms of treatment in Islamic psychotherapy are similar to the ones given by religious figures in Indonesia when providing assistance to individuals with disorders. Thus, this research outcome is expected to be able to formulate the ethics of such treatment within Indonesian context. Furthermore, this research is also expected to be a starting point for the preparation of an ethical code of Islamic psychotherapy in global scale.

\section{References}

Akhmad, P. (2005). Terapi ruqyah sebagai sarana mengobati orang yang tidak sehat mental. Jurnal Psikologi Islami, 1(1), 87-96.

Al-Rabae, A. (2009). Muslim counselors and the western code of ethics. $A l$ 'Adad, 2, 1-84.

Amanah, L., \& Purnamasari, S. E. (2015). 
Efektivitas mendengarkan bacaan Alquran terhadap penurunan tingkat depresi pada lansia. InSight, 17(1), 1128.

Amir, F., Mastutik, G., Hasinuddin, M., \& Putra, S. T. (2018). Dhikr (recitation) and relaxation improve stress perception and reduce blood cortisol level in type 2 diabetes mellitus patients with OAD. Folia Medica Indonesiana, 54(4), 249-255. doi:

$\underline{10.20473 / \text { fmi.v54i4.10707 }}$

Az Zahra, A., \& Saidiyah, S. (2013). Efektivitas pelatihan pemaknaan surat al-insyirah untuk mengurangi stres mahasiswa yang sedang mengerjakan skripsi. Jurnal Intervensi Psikologi (JIP), 5(1), 25-42.

Badri, M. B. (1979). The dilemma of muslim psychologists. London: M.W.H. London Publishers.

Bakri, S., \& Saifuddin, A. (2019). Sufi healing: Integrasi tasawuf dan psikologi dalam penyembuhan psikis dan fisik. Depok: Rajagrafindo Persada.

Brent, D. A., \& Kolko, D. J. (1998). Psychotherapy: Definitions, mechanisms of action, and relationship to etiological models. Journal of Abnormal Child Psychology, 26(1), 17-25. doi: 10.1023/A:1022678622119

Brock, A. C. (2014). History of psychology. In T. Teo (Ed.), Encyclopedia of critical psychology. New York: Springer International Publishing.

Doufesh, H., Ibrahim, F., Ismail, N. A., \& Ahmad, W. A. W. (2014). Effect of muslim prayer (salat) on $\alpha$ electroencephalography and its relationship with autonomic nervous system activity. Journal of Alternative and Complementary Medicine, 20(7), 558562. doi: $\quad \underline{10.1089 / \mathrm{acm} .2013 .0426}$

Fadilah, R. (2015). Pengaruh metoda ruqyah terhadap penurunan derajat kecemasan. Tazkiya Journal of
Psychology, 3(1), 101-112.

Faiz, F. (2007). Kata pengantar: Mengawal perjalanan paradigma. In M. A. Abdullah (Ed.), Islamic studies: Dalam paradigma integrasi interkoneksi (sebuah antologi) (p. viii). Yogyakarta: UIN Suka Press.

Freedheim, D. K., \& Weiner, I. B. (2003). Handbook of psychology vol. 1: History of psychology. New Jersey: John Wiley \& Sons, Inc.

Haque, A., Khan, F., Keshavarzi, H., \& Rothman, A. E. (2016). Integrating islamic traditions in modern psychology: Research trends in last ten years. Journal of Muslim Mental Health, 10(1), 75-100. doi:

10.3998/jmmh.10381607.0010.107

Haryati, A. (2018). Personal integrity of islamic counselor on professional ethics commitment. Islamic Guidance and Counseling Journal, 1(1), 11-16. doi: 10.25217/igcj.v1i1.191

Haslina, C., Abdullah, B., Razali, W. N., Marbawi, M., Taha, B., Kechil, R., \& Sciences, M. (2016). Islamic psychotherapy: Its significance and relevance in the empowerment of Islamic civilization. E-Academia Journal UiTMT, 5(2), 101-105.

Henriques, G. R. (2004). Psychology defined. Journal of Clinical Psychology, 60(12), 1207-1221. doi: 10.1002/jclp.20061

HIMPSI. (2010). Kode etik psikologi Indonesia. Jakarta: Pengurus Pusat Himpunan Psikologi Indonesia.

Howell, J. (2014). Sufism on the silver screen: Indonesian innovations in Islamic televangelism. Journal of Indonesian Islam, 2(2), 225. doi: 10.15642/JIIS.2008.2.2.225-239

Kartika, U., Rosa, E. M., Permana, I., \& Primanda, Y. (2016). Pengaruh shalat dalam menurunkan tingkat ansietas 
dan kadar glukosa darah pada pasien diabetes mellitus tipe 2. Journal of Nursing and Health, 2(1), 29-34.

Kuntowijoyo. (2006). Islam sebagai ilmu: Epistemologi, metodologi, dan etika. Yogyakarta: Tiara Wacana.

Linden, M., \& Schermuly-Haupt, M. L. (2014). Definition, assessment and rate of psychotherapy side effects. World Psychiatry, 13(3), 306-309. doi: 10.1002/wps.20153

Marks, S. (2017). Psychotherapy in historical perspective. History of the Human Sciences, 30(2), 3-16. doi: $\underline{10.1177 / 0952695117703243}$

Mayasari, R. (2013). Islam dan psikoterapi. Afkar, 6(2), 133-156.

Mujib, A. (2017). Teori kepribadian: Perspektif psikologi Islam. Jakarta: Raja Grafindo Persada.

Nashori, F. (2010). Agenda psikologi Islami. Yogyakarta: Pustaka Pelajar.

Nashori, F., Diana, R. R., \& Hidayat, B. (2019). The trends in islamic psychology in Indonesia. In R. W. Hood \& S. Cheruvallil-Contractor (Eds.), Research in the social scientific study of religion, Volume 30 (pp. 162180). Leiden: Brill. doi: $\underline{10.1163 / 9789004416987010}$

Nugraheni, D., Mabruri, M. I., \& Stanislaus, S. (2018). Efektivitas membaca Alquran untuk menurunkan stres akademik pada siswa kelas XI SMA Negeri 1 Kebumen. Intuisi: Jurnal Psikologi Ilmiah, 10(1), 59-71.

Pargament, K. I. (2011). Spiritually integrated psychotherapy: Understanding and addressing the sacred. New York, USA: Guilford Press.

Puji, P. P., \& Hendriwinaya, V. W. (2015). Terapi transpersonal. Buletin Psikologi, 23(2), 92-102. doi: 10.22146/bpsi.10566

Qodar, L., Wijaya, \& Amilda. (2017). Pelaksanaan ibadah sholat dan pengaruhnya terhadap etos kerja. Jurnal Studi Agama, 1(1), 1-14.

Qodariah, S. (2015). Pengaruh terapi ruqyah syar'iyyah terhadap penurunan tingkat kecemasan. Scientica, II(2), 23-37.

Rahmayani, M. P., Rohmatin, E., \& Qulandara, Q. (2018). Pengaruh terapi murottal Alquran terhadap tingkat stres pada pasien abortus di RSUD dr. Soekardjo Kota Tasikmalaya Tahun 2018. Jurnal Bidan, 4(02), 36-41.

Rajab, K. (2006). Islam dan psikoterapi modern. Afkar, 6(2), 133-156.

Richards, P. S., \& Bergin, A. E. (2005). A spiritual strategy for counseling and psychotherapy (2nd Edition). Washington DC, US: American Psychological Association.

Riyadi, A. (2014). Tarekat sebagai organisasi tasawuf (Melacak peran tarekat dalam perkembangan dakwah islamiyah). Jurnal At-Taqaddum, 6(2), 359-385. doi: 10.21580/at.v6i2.716

Roberts, H., \& Petticrew, M. (2006). Systematic reviews in the social sciences: A practical guide. Oxford, United Kingdom: Blackwell Publishing.

Rozehnal, R. (2007). Teaching sufism: Networks of community and discipleship. In Islamic Sufism Unbound. doi: 10.1007/978-0-230-60572-5 5

Salahudin, M. (2016). Amalan tarekat Qadiriyah Wa Naqsabandiyah sebagai proses pendidikan jiwa di Masjid Babul Muttaqin Desa Kradenan Jetis Ponorogo. Esoterik, 2(1), 65-79. doi: $\underline{10.21043 / \text { esoterik.v2i1.1619 }}$

Sari, R. O., Pitoewas, B., \& Yanzi, H. (2018). Pengaruh shalat berjamaah terhadap pembinaan karakter religius peserta didik VIII. Jurnal Kultur Demokrasi, 5(11), 1-15.

Setiawan, I. (2007). Dari pendekatan integratif-interkonektif: Menuju 
pendidikan Islam yang bervisi masa depan (sebuah catatan untuk Fakultas Tarbiyah). In M. A. Abdullah (Ed.), Islamic studies: Dalam paradigma integrasi interkoneksi (sebuah antologi) (pp. 53). Yogyakarta: UIN Suka Press.

Setiawan, W. (2015). Prosesi baiat jama'ah Tarekat Sattariyyah, Paju, Ponorogo (Sebuah kajian fenomenologi). $A l$ Murabbi, 01(02), 63-76.

Setyawan, S. D., \& Purwanto, Y. (2006). Fenomena terapi ruqyah dan perkembangan kondisi afeksi klien. Indigenous, Jurnal Ilmiah Berkala Psikologi, $8(2), 65-75$.

Siddaway, A. P., Wood, A. M., \& Hedges, L. V. (2019). How to do a systematic review: A best practice guide for conducting and reporting narrative reviews, meta-analyses, and metasyntheses. Annual Review of Psychology, 70, 747-770. doi: 10.1146/annurevpsych-010418-102803

Soliman, H., \& Mohamed, S. (2013). Effects of zikr meditation and jaw relaxation on postoperative pain, anxiety and physiologic response of patients undergoing abdominal surgery. Journal of Biology, Agriculture and Healthcare, 3(2), 22-38.
Susanto, D. (2014). Dakwah melalui layanan psikoterapi ruqyah bagi pasien penderita kesurupan. Konseling Religi: Jurnal Bimbingan Konseling Islam, 5(2), 313-334.

Trimulyaningsih, N., Wulandari, E., \& Sofia, N. (2017). Qualitative research on islamic psychotherapy: A metasynthesis study in Indonesia. COUNSEDU: The International Journal of Counseling and Education, 2(3), 119-130. doi: $\underline{10.23916 / 002017025630}$

Ummah, E. O. S. S. (2018). Tarekat, kesalehan ritual, spiritual dan sosial: Praktik pengamalan tarekat syadziliyah di Banten. Al-A'raf: Jurnal Pemikiran Islam dan Filsafat, XV(2), 315334. doi: 10.22515/ajpif.v15i2.1448

Wardani, Y., Nashori, F., \& Uyun, Q. (2016). Efektivitas pelatihan shalat khusyuk dalam menurunkan kecemasan pada lansia hipertensi. Jurnal Intervensi Psikologi (JIP), 8(2), 217-233.

Wood, S. E., Wood, E. G., \& Boyeld, D. G. (2014). An introduction to mastering psychology. In Mastering the World of Psychology. doi: 10.1037/11202-000

Zed, M. (2016). Metode penelitian kepustakaan. Jakarta: Yayasan Obor Nasional. 